\title{
CIĄGLOŚĆ PRAWNA WSKAŹNIKÓW REFERENCYJNYCH STOPY PROCENTOWEJ
}

\section{WPROWADZENIE}

Rozwojowi rynku finansowego towarzyszył wzrost znaczenia wskaźników referencyjnych stopy procentowej - są one bazą dla instrumentów pochodnych $^{1}$ oraz służą na przykład do wyliczania kosztu kredytu. Reakcja takich wskaźników jest też kanałem transmisji impulsów polityki pieniężnej²

Przez niemal cały okres funkcjonowania wspomnianych wskaźników ich wyznaczanie było działalnością nieregulowaną. Kryzys finansowy uwidocznił jednak ich podatność na manipulację, co podważając zaufanie do mechanizmu rynkowego, skutkowało spadkiem płynności. W efekcie ujawniła się luka regulacyjna, której wypełnienie możliwe jest przez rekomendacje międzynarodowe bądź lokalnie wprowadzane przepisy. Osią rozważań prowadzonych w niniejszym artykule jest hipoteza, że modyfikacja procesu opracowywania wskaźników referencyjnych stopy procentowej nie stanowi ich istotnej zmiany i nie może być przesłanką unieważnienia umów, w których stosowano odesłanie do wskaźnika. Zakres czasowy analizy nakierowanej na konfirmację powyższej hipotezy to generalnie lata 2018-2019, czyli okres, w którym zreformowano zasady opracowywania LIBOR oraz EURIBOR ${ }^{3}$. Wymienione wskaźniki referencyjne, których wskazanie jest równocześnie dookreśleniem zakresu przedmiotowego badania zamieszczonego w niniejszej pracy, wybrano ze względu na skalę ich stosowania na rynku finansowym Unii Europejskiej. Z racji bardzo dużej wartości i mnogości instrumentów finansowych, które w swej konstrukcji odwołują się do LIBOR lub EURIBOR, falsyfikacja postawionej wyżej hipotezy może oznaczać zagrożenie dla stabilności finansowej, czyli zaprzeczenie ratio legis wprowadzenia przepisów prawa UE poddajacych opracowywanie wskaźników referencyjnych nadzorowi publicznemu.

Powyższe stwierdzenie stanowi motywację powstania niniejszego artykułu, w którym wykorzystano metodę dogmatyczną skoncentrowaną na analizie przepisów prawa Unii Europejskiej oraz komparatystykę ich stosowania

${ }^{1}$ Klein (2004): 46-57 i cytowana tam literatura.

${ }^{2}$ Creel, Hubert, Viennot (2016): 4474-4501; Kapuściński et al. (2016): 64-93.

${ }^{3}$ LIBOR do 2017 r. był akronimem pochodzacym od London Interbank Bank Offered Rate. Obecny administrator nie stosuje już tego określenia i poprzestaje na użyciu oznaczania LIBOR IBA (2017): 1. EURIBOR nadal jest skrótowcem Euro Interbank Offered Rate - EMMI (2019a): 2. 
w Wielkiej Brytanii oraz strefie euro. Ze względu na przedmiot prowadzonej analizy, który stanowi element swoistej infrastruktury rynku finansowego, konieczne było także sięgnięcie do metod badawczych przynależnych ekonomii. W tym przypadku skorzystano z podstawowych metod statystycznych (narzędzi statystyki opisowej oraz wnioskowania statystycznego dotyczącego związków korelacyjnych). Ponadto szeroko korzystano z krytycznego przeglądu literatury przedmiotu.

\section{EKONOMICZNE ORAZ PRAWNE PRZESLANKI ZMIANY MECHANIZMU USTALANIA LIBOR I EURIBOR}

Metoda wyznaczania wskaźników referencyjnych stopy procentowej w Unii Europejskiej była wzorowana na LIBOR. Uważa się, że pierwszy raz zastosowano ten wskaźnik w 1969 r., udzielając szachowi Iranu kredytu o oprocentowaniu wyliczanym jako średnia arytmetyczna ofert uczestników konsorcjum ${ }^{4}$. Dopiero w 1986 r. spisano zasady kalkulowania LIBOR i określono panel kwotujących banków. Za cały proces odpowiadało British Bankers' Association (BBA) ${ }^{5}$.

Państwa przystępujące do strefy euro uznały, że nowa waluta oznacza rezygnację z lokalnych wskaźników referencyjnych. Opracowanie kontynentalnego wskaźnika odwołującego się do euro przyjęła na siebie European Banking Federation (EBF) z Brukseli, a obecnie European Money Market Institue (EMMI). Pierwszy raz EURIBOR wyznaczono 4 stycznia 1999 r. ${ }^{6}$ Od maja 2019 r. panel EURIBOR liczy 18 banków.

Najważniejsze dla przedkryzysowego sposobu wyznaczania LIBOR było pytanie: ile wyniesie oprocentowanie środków, które pozyskasz, akceptując ofertę międzybankowa przedstawioną tuż przed godzina 11.00, zakładając normalny stan rynku? Udzielenie eksperckiej odpowiedzi było tzw. kwotowaniem. EURIBOR był zaś definiowany jako oprocentowanie, po którym czołowy bank z UE bądź EFTA jest gotowy zaoferować innemu czołowemu bankowi depozyt niezabezpieczony w euro, a oferta jest składana o godz. 11.007. Zatem panelista LIBOR odpowiadał w swoim imieniu, a w panelu EURIBOR banki informowały o ofercie hipotetycznego banku. Wyliczenie LIBOR bądź EURIBOR było średnią arytmetyczną z kwotowań przekazanych do tzw. agenta kalkulacyjnego ${ }^{8}$.

${ }^{4}$ Vaughan, Finch (2017): 14.

${ }^{5}$ Więcej o zasadach ustalania LIBOR w procesie tzw. fixing piszą Gyntelberg, Wooldridge (2008): 61-65.

${ }^{6}$ Hörth (1998): 11.

${ }^{7}$ O ustalaniu EURIBOR w trakcie fixingu piszą Eisl, Jankowitsch, Subrahmanyam (2017): 611-612.

${ }^{8} \mathrm{~W}$ związku ze zmienną liczebnością panelu odrzucano od 1 do 4 (LIBOR) lub od 2 do 8 (EURIBOR) najwyższych i najniższych kwotowań. Agentem kalkulacyjnym z reguły była agencja informacyjna dystrybuująca wyliczone wskaźniki referencyjne. Przykładem jest Thomson Reuters. 
Powyżej przedstawiony mechanizm nawiązywał do funkcji, jaką pełnił międzybankowy rynek depozytów niezabezpieczonych przed kryzysem finansowym. Podobnie jak w przypadku każdego rynku należy na niego spojrzeć jak na miejsce kształtowania się ceny równoważącej wielkość zapotrzebowania i ilość oferowaną do sprzedania. W przypadku rynku pieniężnego swoiście pojmowaną cena jest stopa procentowa, a zapotrzebowanie (popyt) i podaż dotyczą krótkoterminowego kapitału pieniężnego ${ }^{9}$. Strona popytowa dąży do nabycia płynności, strona podażowa pragnie ulokować nadwyżkowe (w stosunku do bieżących potrzeb wydatkowych) kapitały pieniężne, licząc na przychody.

Rynek międzybankowy jest specyficznym segmentem rynku pieniężnego, gdyż tylko w jego przypadku popyt i podaż sa kreowane przez banki. W odniesieniu do innych instrumentów egzemplifikujacych krótkoterminowy kapitał pieniężny zapotrzebowanie na płynność jest także zgłaszane przez rządy (bony skarbowe) lub podmioty niefinansowe (krótkoterminowe wartościowe papiery dłużne). Podobnie podaż tego rodzaju kapitału pieniężnego może pochodzić spoza sfery bankowej. Przykładami są fundusze inwestycyjne (zwłaszcza fundusze rynku pieniężnego).

Od lat osiemdziesiatych ubiegłego wieku systematycznie rosło znaczenie lokat międzybankowych w bilansach banków komercyjnych ${ }^{10}$. Pozwalały one na sprawną alokację ${ }^{11}$ płynności rozumiana jako zdolność do rozmieszczania kapitału pieniężnego między bankami występującymi w roli pożyczkobiorców i pożyczkodawców. Dodatkowo wyliczane wskaźniki referencyjne stopy procentowej stanowiły, jak się wydawało, weryfikowalną wycenę krótkoterminowego kapitału pieniężnego ${ }^{12}$.

Tłumaczy to coraz szersze korzystanie ze wspomnianych wskaźników w klauzulach odsetkowych kredytów wykorzystujących mechanizm zmiennej stopy procentowej. Po pierwsze, kredytodawca mógł się posiłkować niejako parametryzacją swojej polityki cenowej. Po drugie, kredytobiorca zyskiwał możliwość sprawdzenia poprawności naliczanego oprocentowania. Po trzecie, tworzył się istotny kanał transmisji impulsów polityki pieniężnej banku centralnego na rynek bankowy, a następnie do sfery realnej finansowanej kredytami.

9 Szerzej na ten temat pisze Gruszyńska-Brożbar (1999): 137-138. W praktyce funkcjonowania rynku finansowego przyjęło się traktować okres jako synonim pierwotnego terminu zapadalności instrumentów finansowych, którymi się obraca. Krótkoterminowy kapitał pieniężny jest substratem tych instrumentów, których wspomniany termin zapadalności nie przekracza 12 miesięcy. Zob. Mishkin, Eakins (2015): 292-300.

${ }^{10}$ Lubiński (2013): 26.

11 Takie znaczenie alokacji kapitału pieniężnego stosuje m.in. Nawrot (2008): 29.

${ }^{12} \mathrm{~W}$ latach bezpośrednio poprzedzających kryzys finansowy rynek międzybankowy zaczął również służyć transformacji kapitału, zwłaszcza terminowej. Pasywa pochodzące z tego źródła ex definitione krótkoterminowe - w coraz większym stopniu zaczęto wykorzystywać do finansowania aktywów kredytowych, w tym długoterminowych kredytów hipotecznych. Przykładem może być Irlandia, gdzie w okresie boomu kredytowego kapitał pieniężny pochodzący z globalnego rynku międzybankowego stanowił 60\% źródeł finansowania akcji kredytowej banków - Chmielewski, Sławiński (2010): 51. 
Wskaźniki referencyjne stopy procentowej stały się także bardzo ważnym tzw. instrumentem bazowym dla instrumentów pochodnych ${ }^{13}$. Wystawiane instrumenty pochodne początkowo służyły zabezpieczaniu ryzyka stopy procentowej, by z czasem stać się niejako samoistnym przedmiotem obrotu o charakterze spekulacyjnym.

Funkcjonowanie wskaźników referencyjnych stóp procentowych stanęło po 2008 r. w obliczu dwóch wyzwań. Pierwszym jest zmiana struktury rynku lokacyjnych instrumentów pieniężnych, szczególnie widoczna w strefie euro (zob. wykres 1). O ile przeciętny dzienny obrót systematycznie rośnie i w 2018 r. sięgną 650 mld euro, o tyle spadł udział transakcji niezabezpieczonych. Przed kryzysem finansowym wynosił on blisko 35\%, podczas gdy w 2018 r. tylko 3\%. Dodatkowo, jak dowodzą dane zamieszczone w tabeli 1, płynność skoncentrowana została w najkrótszych terminach zapadalności

Powyższe zmiany można tłumaczyć pokryzysową awersją do niezabezpieczonego ryzyka kredytowego immanentnie zawiąanego z lokowaniem kapitału pieniężnego. Rynek pieniężny prawidłowo spełnia swe funkcje, jeżeli podmioty na nim operujące sa przeświadczone, że pozostali uczestnicy wymiany będą akceptować swoje zobowiązania bez zastrzeżeń, przy krótkim terminie wypowiedzenia i niewielkim ryzyku cenowym. Brak zabezpieczenia lokat międzybankowych stymulować więc powinien monitorowanie sytuacji ekonomicznej kontrahenta i eliminowanie z tego segmentu najsłabszych podmiotów. Wymusza to na pożyczkobiorcach dbałość o reputację (dyscyplinę rynkowa), pozwalająca na zapatrywanie się w płynność na rynku pieniężnym przy relatywnie niskich kosztach ${ }^{14}$.

Kryzys finansowy ujawnił jednak błędy we wspomnianym monitorowaniu i egzekwowaniu dyscypliny rynkowej. Obawa przed dostarczeniem płynności do banku, którego ryzyko kredytowe zostało nieprawidłowo ustalone (zaniżone), gwałtownie zmniejszyła podaż kapitału na rynku międzybankowym, a równocześnie podmioty o słabszej kondycji wyraźnie zwiększyły popyt na płynność. Reakcją rynkową było skurczenie się wartości wymiany przy silnym wzroście wyceny kapitału ${ }^{15}$.

Dopiero interwencja banków centralnych inicjujacych tzw. niestandardową politykę pieniężną zapewniła bankom odpowiednią do ówczesnych potrzeb płynność. Ta praktyka najważniejszych banków centralnych jest kontynuowana i stanowi strukturalną substytucję zaopatrywania się w płynność na rynku międzybankowym. Ponadto w Unii Europejskiej w 2014 r. weszły w życie wymogi bazylejskie dotyczące płynności krótkoterminowej, niejako penalizując pozyskiwanie finansowania na rynku hurtowym ${ }^{16}$. Tym samym rynek międzybankowy przestał być traktowany jako realne źródło pozyskiwania kapitału pieniężnego, który może być przedmiotem transformacji w długoterminowe aktywa kredytowe.

\footnotetext{
${ }^{13}$ Istotę takich instrumentów objaśnia Bianchetti (2013): 113-152.

${ }^{14}$ Zob. Lubiński (2013): 23.

${ }^{15}$ Georg (2011): 2-3.

${ }^{16}$ Szerzej na ten temat piszą Tabb, Grundfest (2013): 234-235.
} 
Wykres 1

Wartość obrotu i struktura rynku pieniężnego

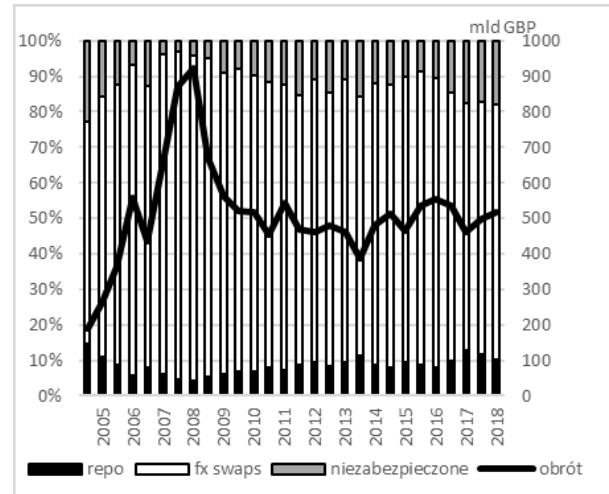

a) Wielka Brytania (rynek GBP) w latach 2005-2018

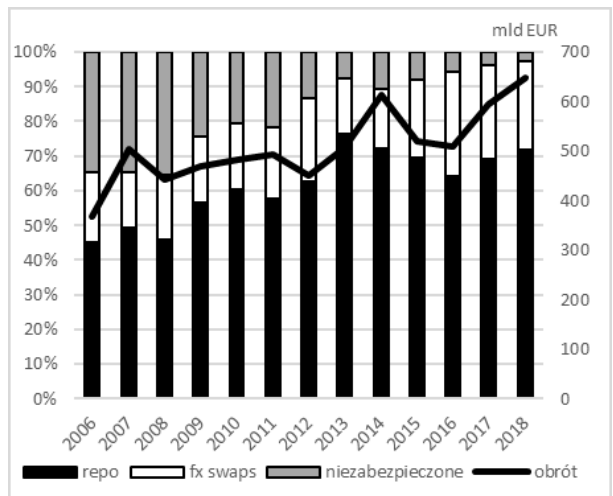

b) strefa euro w latach $2003-2018$

Źródło: opracowanie własne na podstawie bazy danych Banku Anglii oraz EBC.

\section{Tabela 1}

Struktura terminowa niezabezpieczonych transakcji depozytowych na rynku międzybankowym

\begin{tabular}{|c|c|c|c|c|c|c|}
\hline \multirow{3}{*}{ Okres } & \multicolumn{4}{|c|}{ Udział w przeciętnej dziennej wartości obrotu [w \%] } \\
\cline { 2 - 7 } & \multicolumn{2}{|c|}{ overnight } & \multicolumn{2}{c|}{ T/N-2W } & \multicolumn{2}{c|}{ 1M-6M } \\
\cline { 2 - 7 } & $\begin{array}{c}\text { Wielka } \\
\text { Brytania }\end{array}$ & $\begin{array}{c}\text { strefa } \\
\text { euro }\end{array}$ & $\begin{array}{c}\text { Wielka } \\
\text { Brytania }\end{array}$ & $\begin{array}{c}\text { strefa } \\
\text { euro }\end{array}$ & $\begin{array}{c}\text { Wielka } \\
\text { Brytania }\end{array}$ & $\begin{array}{c}\text { strefa } \\
\text { euro }\end{array}$ \\
\hline I połowa 2008 & $\mathrm{n} / \mathrm{a}$ & 14,62 & $\mathrm{n} / \mathrm{a}$ & 12,12 & $\mathrm{n} / \mathrm{a}$ & 47,25 \\
I połowa 2016 & 91,54 & 56,05 & 6,42 & 7,22 & 1,72 & 36,75 \\
\hline I połowa 2018 & 89,77 & 59,03 & 8,29 & 5,42 & 1,50 & 34,97 \\
\hline
\end{tabular}

Objaśnienia: dla Wielkiej Brytanii pokazano strukturę depozytów w GBP; udziały nie sumuja się do $100 \% ; \mathrm{n} / \mathrm{a}$ - brak danych.

Źródło: jak na wykresie 1.

Drugim czynnikiem determinującym zmiany wyznaczania LIBOR i EURIBOR jest ujawniona podatność wskaźników referencyjnych stóp procentowych na manipulacje. Wynikała ona z braku powiązania informacji dostarczanych przez uczestników panelu z faktycznymi transakcjami, które zawierali na rynku międzybankowym. Dzięki temu niektóre banki mogły generować dodatkowe zyski na instrumentach pochodnych zależnych od LIBOR bądź EURIBOR. Współdziałanie dealerów derywatów oraz kwotujących mogło zaburzać równowagę rynkową ${ }^{17}$. Ponadto chciano wskazać, że

17 Ashton, Christophers (2015): 191; Martin (2013): 90-91. 
koszty finansowania się na rynku międzybankowym są niższe niż u konkurencji, co oznacza wyższą wiarygodność.

Informacje o możliwości zniekształcania wskaźników referencyjnych stóp procentowych pojawiły się w $2008 \mathrm{r} \cdot{ }^{18} \mathrm{~W}$ efekcie organy nadzoru podjęły działania wyjaśniające. Za niewłaściwe praktyki 10 globalnych banków musiało zapłacić kary oscylujące wokół 9 mld USD ${ }^{19}$.

Podważenie zaufania do efektywności rynku międzybankowego i rzetelności wyceny krótkoterminowego kapitału pieniężnego, który jest przedmiotem dokonywanych na nim transakcji, mogło zagrozić stabilności systemu finansowego. Wymusiło to działania kreatorów regulacji finansowych - w tym przypadku Międzynarodowej Organizacji Komisji Papierów Wartościowych (IOSCO) oraz Rady Stabilności Finansowej (FSB) ${ }^{20}$, którzy zalecili, by informacje stanowiące podstawę wyznaczania wskaźników referencyjnych szeroko wykorzystywały dane identyfikujące faktycznie realizowane transakcje. Dlatego mechanizm ustalania LIBOR oraz EURIBOR wymagał reformy.

Sugestie IOSCO i FSB to zalecenia, których nieprzestrzeganie nie rodzi sankcji, a Komisja Europejska uznała, że te wymagania należy przekuć w przepisy. Dodatkowa przesłanką była chęć uniknięcia arbitrażu regulacyjnego, który groził w obliczu już uchwalonych norm brytyjskich oraz belgijskich.

Właściwym aktem prawnym UE jest rozporządzenie Parlamentu Europejskiego i Rady (UE) 2016/1011 z 8 czerwca 2016 r. w sprawie indeksów stosowanych jako wskaźniki referencyjne w instrumentach finansowych i umowach finansowych lub do pomiaru wyników funduszy inwestycyjnych [...] - dalej określane jako BMR ${ }^{21}$. Stosownie do art. 3 ust. 1 pkt 3 BMR zawęża się pojęcie wskaźnika referencyjnego do indeksu stosowanego do określenia kwoty przypadającej do zapłaty z tytułu instrumentu finansowego lub umowy finansowej lub do określenia wartości instrumentu finansowego bądź indeksu stosowanego do pomiaru wyników funduszu inwestycyjnego, określenia alokacji aktywów lub obliczania opłat za wyniki. Umową finansowa jest zaś umowa o kredyt zawarta z konsumentem, a instrumentami finansowymi są te ujęte w dyrektywie MiFID II i dopuszczone do systemu obrotu $^{22}$.

BMR stanowi, że podmioty nadzorowane mogą stosować tylko wskaźniki opracowywane przez administratorów wpisanych do właściwego rejestru. Administrator musi uzyskać autoryzację organu nadzoru i dopiero potem może być ujawniony w rejestrze Europejskiego Urzędu Nadzoru Giełd i Papierów Wartościowych.

\footnotetext{
18 Mollenkamp, Whitehouse (2008); Ewerhart et al. (2007); Gyntelberg, Wooldridge (2008).

19 McBride (2016); Ashton, Christophers (2015): 198-199.

20 Syntetyczne ujęcie wytycznych IOSCO prezentuje Berman (2015): 108-110.

21 Dz. Urz. UE L 171 z 29.06.2016 r. ze zm.

${ }^{22}$ Co oznacza, że obraca się nimi na rynku regulowanym lub platformach obrotu.
} 


\section{DOSTOSOWANIE LIBOR I EURIBOR DO WYMOGÓW BMR}

Ewolucja LIBOR rozpoczęła się od tzw. raportu Wheatleya. Zawarto tam rekomendacje dotyczace: poddania procesu wyznaczania LIBOR nadzorowi publicznemu, zmiany podmiotu opracowujaccego, wzmocnienia ładu korporacyjnego nowego administratora, szerokiego wykorzystanie danych transakcyjnych oraz rozpoczęcia wyznaczania wskaźników alternatywnych dla LIBOR ${ }^{23}$.

Najważniejszym etapem dostosowania LIBOR do przepisów Unii Europejskiej było przygotowanie tzw. kaskady danych. Chodziło o sprostanie wymogom art. 11 ust. 1 BMR, stanowiacym, że dane wejściowe muszą być wystarczajace do dokładnego i wiarygodnego odzwierciedlenia rynku lub realiów gospodarczych, których pomiar jest celem wskaźnika referencyjnego. Załącznik I BMR nakazuje administratorowi nadanie pierwszeństwa danym o transakcjach. Gdy takie informacje są niewystarczające, należy sięgnąc do transakcji z rynków powiązanych, a dopiero potem do kwotowań eksperckich.

Założenia kaskady danych LIBOR ustalono w 2016 r. W związku z tym IBA (obecny administrator) definiuje LIBOR jako stopę procentową hurtowego finansowania się, która w największym możliwym zakresie bazuje na niezabezpieczonych transakcjach banków należących do panelu LIBOR. Odstąpiono więc od zawężenia źródła finansowania, jak też podkreślono, że zamiast opinii eksperckiej pierwszeństwo mają informacje o operacjach rynkowych.

W kaskadzie danych LIBOR najważniejsze jest ważone wolumenem średnie oprocentowanie depozytów z hurtowego rynku pieniężnego. Do tego segmentu IBA zalicza transakcje $\mathrm{z}$ bankami centralnymi i rozwoju, instytucjami publicznymi, niebankowymi instytucjami finansowymi oraz przedsiębiorstwami niefinansowymi. Jeśli nie zawierano takich transakcji, to bank ma sięgnąć do danych z przeszłości. Trzecim poziomem jest ocena ekspercka, ale bazująca na analizie danych rynkowych.

Korzystając z tej hierarchii, bank jest zobowiązany do przekazania IBA wyliczenia oprocentowania. Informacje uśrednia się po odrzuceniu wartości skrajnych. Zatem algorytm numeryczny ustalenia LIBOR jest ten sam, choć dane wejściowe mają innych charakter. Po ustaleniu powyższych zasad IBA przystapiła do testów tej metody, a z uwagi na to, że uczestnicy panelu udowodnili zdolność do posługiwania się metodą kaskadowa, IBA złożyła do Financial Conduct Authority (FCA) wniosek o zezwolenie na pełnienie funkcji administratora i w kwietniu 2018 r. uzyskała autoryzację $e^{24}$.

Dostosowanie EURIBOR do wymogów BMR okazało się nieco dłuższe. Początkowo EMMI uznała, że możliwe jest wyliczenie stopy wyłącznie na bazie oprocentowaniu niezabezpieczonych depozytów międzybankowych (EURIBOR+). Wybór takiej drogi był prawdopodobnie motywowany wiara, że analizując aktywność 31 banków z 12 państw strefy euro (czyli szerszego grona niż panel), pozyska się wystarczający zasób transakcyjny. Stawiając

\footnotetext{
${ }^{23}$ HM Treasury (2012): 6.

${ }^{24}$ IBA (2018).
} 
tezę, że ekspercki EURIBOR będzie zbliżony do EURIBOR+, EMMI optowała za natychmiastową substytucją (seamless transition) ${ }^{25}$.

W 2017 r. okazało się, że znaczna część biorących w badaniu banków nie przyjmuje depozytów zdefiniowanych przez EMMI. Druga konstatacją było stwierdzenie, że EURIBOR+ nie posiada cech uprawniajacych do seamless transition. Należy założyć, że EURIBOR+ wykazywał zbyt dużą zmienność, która mogłaby skutkować naruszeniem ciagłości istniejących kontraktów.

Fiasko tej fazy spowodowało rozpoczęcie prac nad połączeniem danych transakcyjnych z kwotowaniami ${ }^{26}$. Warunkiem koniecznym wykorzystania kaskady danych była zmiana definicji EURIBOR i EMMI odseparowała opis rynku od sposobu pomiaru. W obecnie obowiazujących dokumentach ${ }^{27}$ EURIBOR jest ujmowany jako stopa procentowa mierzaca koszt hurtowego finansowania się instytucji kredytowych z państw UE i EFTA na niezabezpieczonym rynku pieniężnym euro.

Kaskada EURIBOR też składa się z trzech poziomów. Pierwszym jest średnie (ważone wolumenem) oprocentowanie niezabezpieczonych depozytów. Depozyty mają być składane przez inne banki, instytucje finansowe oraz instytucje publiczne ${ }^{28}$. Drugim poziomem sa ekstrapolowane dane o transakcjach historycznych. Trzecią warstwą są informacje o operacjach na rynkach powiązanych, np. instrumentów pochodnych, oraz dane wynikające z oceny eksperckiej. Konieczne jest wskazanie, że w metodach kaskadowych obu uwzględnianych wskaźnikach referencyjnych stopy procentowej stosuje się obecnie „okna czasowe" zbierania danych. Oznacza to, że banki raportują o transakcjach zawieranych w poprzednich, z góry ustalonych okresach. Zastępuje to pomiar $\mathrm{w}$ danym dniu i utrudnia manipulacje ${ }^{29}$.

EMMI też przeprowadziła testowe wyliczanie EURIBOR na podstawie metody hybrydowej i zbadała zdolność banków do posługiwania się nią. W opinii administratora wyniki dały podstawę do wystapienia z wnioskiem o wydanie zezwolenia, co też stało się na mocy decyzji belgijskiego organ nadzoru (FSMA) z 2 lipca 2019 r. ${ }^{30}$. Dzięki temu EMMI została wpisana do rejestru administratorów.

\section{ISTOTNA ZMIANA METODY OPRACOWYWANIA LIBOR I EURIBOR - UJĘCIE PRAWNO-EKONOMICZNE}

Modyfikacje adaptujące wyznaczanie LIBOR i EURIBOR do przepisów BMR należy ocenić z punktu widzenia potencjalnej istotnej zmiany tego procesu. Jest to kluczowy aspekt reformy, gdyż tego rodzaju zmiana może budzić

\footnotetext{
${ }^{25}$ Mielus (2016): 106.

${ }^{26}$ EMMI (2017): 11.

${ }^{27}$ EMMI (2019a): 5.

${ }^{28}$ Wyłączono przedsiębiorstwa niefinansowe.

${ }^{29}$ O walorach takiego podejścia piszą Duffie, Stein (2015): 191.

${ }^{30}$ FSMA (2019).
} 
wątpliwość co do ważności umów, w których pojawiło się odwołanie do danego wskaźnika referencyjnego stopy procentowej. Dotychczasowa skala wykorzystania analizowanych wskaźników referencyjnych wskazuje, że podważanie konieczności wywiązania się z zaciagniętych zobowiązań może stanowić istotne zagrożenie dla stabilności międzynarodowego rynku finansowego.

Niestety nie istnieja ujednolicone dane identyfikujące wskazaną skalę. Wydaje się, że najczęściej cytowanym źródłem jest raport opracowany pod auspicjami FSB ${ }^{31}$ : w 2012 r. wartość umów wykorzystujących LIBOR była nie mniejsza niż 220 bilionów USD, z czego około 70\% przypadało na LIBOR USD. Nowsze szacunki ${ }^{32}$ wskazuja, że w 2016 r. ekspozycja na LIBOR USD wynosiła 200 bilionów USD ${ }^{33}$. Zachowując proporcje walutowe z 2012 r., łączna ekspozycja na LIBOR jest zbliżona do 300 bilionów USD.

Według Europejskiego Banku Centralnego (EBC) w 2018 r. wartość instrumentów pochodnych związanych z EURIBOR wynosiła co najmniej 110 bilionów euro ${ }^{34}$. Wartość kredytów zbliżała się do 10 bilionów euro, a emisja papierów dłużnych wynosiła około 1,5 biliona euro ${ }^{35}$.

Podkreślić należy, że BMR używa terminu ,istotna zmiana metody opracowywania wskaźnika referncyjnego", ale nie wskazuje elementów warunkujących jej wystapienie. Dlatego konieczne jest zrozumienie zarówno aspektów prawnych, jak i ekonomicznych przeprowadzonych dotąd modyfikacji LIBOR i EURIBOR.

W przypadku uwarunkowań prawnych jako do swoistego studium przypadku można odwołać się do konstrukcji kredytu hipotecznego ze zmienną stopą procentowa, zależną od kształtowania się badanego wskaźnika referencyjnego. Standardem rynkowym jest wówczas wprowadzanie do umowy kredytu klauzuli odsetkowej składającej się z podania nazwy wskaźnika referencyjnego stopy procentowej powiększonej o narzut (marżę) wyrażony w punktach procentowych ${ }^{36}$.

Zwyczajem było dodawanie do nazwy wskaźnika referencyjnego informacji o podmiocie, który go opracowuje - co od czasu wejścia w życie BMR jest już obowiązkiem wynikajacym z przepisów prawa UE. Zgodnie z wcześniejszymi uwagami w ostatnich dwóch dekadach dochodziło jednak do zmiany takich podmiotów.

Mimo wszystko należy uznać, że mechanizm zmiennej stopy procentowej nadal działa. Po pierwsze, osoby prawne przejmujące opracowywanie wstępowały we wszelkie prawa i obowiązki swoich poprzedników ${ }^{37}$. Po drugie, elementem, który może być oceniany z punktu widzenia ewentualnych nie-

31 MPG (2014): 19-20.

32 ARRC (2018): 2.

33 Stanowiło to 11-krotność PKB Stanów Zjednoczonych z tego okresu.

${ }^{34} \operatorname{EBC}(2018 \mathrm{a})$.

35 Suma ekspozycja wynosząca około 122 bilionów euro to ponownie około 11 razy więcej niż PKB strefy euro z końca roku 2017 r.

36 Penczar (2017): 133.

$37 \mathrm{~W}$ przypadku BBA i IBA podpisano odpowiednią umowę na gruncie prawa brytyjskiego. Dodatkowo cały proces przejmowania odbywal się pod kuratelą specjalnie powołanego komitetu rządowego - Ashton, Christophers (2015): 212. 
uczciwych warunków w umowach konsumenckich ${ }^{38}$, jest możliwość zrozumienia konsekwencji ekonomicznych zmieniającej się stopy procentowej. Nazwa podmiotu opracowującego wskaźnik referencyjny jest z tego puntu widzenia irrelewantna, gdyż nie stanowi elementu konstytutywnego dla metody opracowywania wskaźnika referencyjnego. Po trzecie, normodawca europejski odseparował wskaźnik referencyjny i mechanizm jego wyznaczania od osoby (prawnej lub fizycznej), która prowadzi ten proces. Powyższy wniosek wynika z treści art. 21 ust. 2 lit. b BMR, w którym właściwy organ nadzoru uzyskuje uprawnienie do oceny „sposobu, w jaki wskaźnik referencyjny ma zostać powierzony nowemu administratorowi”. Podsumowując powyższe uwagi, należy stwierdzić, że nie ma podstaw prawnych do tego, by zmianę administratora uznać na przesłankę zmiany wskaźnika referencyjnego stopy procentowej.

Kolejnym przepisem, na który trzeba zwrócić uwagę, jest art. 13 ust. 1 lit. c BMR, który wymaga, by administrator wskaźnika referencyjnego ustanowił procedurę konsultacji w sprawie istotnej zmiany metody opracowywania wskaźnika. Równocześnie art. 28 ust. 1 BMR kreuje obowiązek opracowania przez administratora procedury działań podejmowanych na wypadek dokonania istotnej zmiany wskaźnika ${ }^{39}$. Jak dotąd administratorzy nie skorzystali z tych procedur, a więc uznali, że nie doszło do istotnej zmiany. Ze względu na to, że obaj administratorzy podlegaja już nadzorowi właściwych organów publicznych i nie zostały wobec nich wyciagnięte konsekwencje za ewentualne naruszenie powyżej przytoczonych przepisów, można przyjąć, że wnioski do, jakich doszli administratorzy, sa (per facta concludentia) potwierdzone przez nadzór finansowy.

W opinii autora konieczne jest jednak także przeprowadzenie analizy ilościowej LIBOR i EURIBOR równolegle wyznaczanych metodą kaskadową i ekspercka. Odpowiednio był to okres od 15 września do 15 grudnia $2017 \mathrm{r}$. oraz od 2 maja do 31 lipca 2018 r. Uwzględniono zmiany ich poziomów (zob. wykres 2) oraz korelację. Uzyskane współczynniki korelacji zawarto w tabeli 2.

Współczynniki zawarte w tabeli 2 wskazują na istnienie silnej i dodatniej korelacji przebiegu wskaźników referencyjnych stóp procentowych wyznaczanych analizowanymi metodami. Zatem wprowadzenie hierarchicznej kaskady danych nie wpłynęło w sposób statystycznie istotny na kierunek zmian wyceny krótkoterminowego kapitału pieniężnego. Krzywe zobrazowane na wykresie 2 pozwalają zauważa, że przejście na metodę kaskadową w obu przypadkach skutkowało przesunięciem w dół poziomu wskaźników referencyjnych. Należy to wiązać z uszczegółowieniem definicji, wskazującej, że istotą LIBOR i EURIBOR jest przyjmowanie depozytów. Obserwacja krzywych z wykresu 2 pozwala też zauważyć, że szeregi czasowe obrazujące metodę kaskadową charakteryzują się większą dynamiką zmian, którą kwantyfikuje zmienność, czyli cecha typowa dla

${ }^{38}$ Linia orzecznicza Trybunału Sprawiedliwości Unii Europejskiej wskazuje, że umowy kredytu hipotecznego, którego stroną jest konsument, podlegają ocenie z punktu widzenia spełniania wymogów dyrektywy Rady 93/13/EWG z 5 kwietnia 1993 r. w sprawie nieuczciwych warunków w umowach konsumenckich.

39 Są to odpowiednio IBA (2019); EMMI (2019b). 
rynków finansowych ${ }^{40}$. Jednak w odniesieniu do indywidualnie ujmowanych terminów zapadalności w żadnych z przypadków nie odnotowano różnicy większej niż 10 punktów bazowych w porównaniu z metodą ekspercką.

\section{Tabela 2}

Współczynnik korelacji rang Spearmana dla wskaźników referencyjnych stopy procentowej obliczanych metodą ekspercką i kaskadową

\begin{tabular}{|l|c|c|c|c|}
\hline \multirow{2}{*}{$\begin{array}{c}\text { Wskaźnik referencyjny } \\
\text { stopy procentowej }\end{array}$} & \multicolumn{4}{|c|}{ Zapadalność } \\
\cline { 2 - 5 } & $\mathbf{1 M}$ & $\mathbf{3 M}$ & $\mathbf{6 M}$ & $\mathbf{1 2 M}$ \\
\hline EURIBOR & 0,372 & 0,642 & 0,483 & 0,879 \\
\hline LIBOR & 0,842 & 0,956 & 0,917 & 0,908 \\
\hline
\end{tabular}

Objaśnienie: z uwagi na dalszą analizę decyzji brytyjskiego organu nadzoru w sprawie LIBOR ten wskaźnik referencyjnych stopy procentowej był uwzględniany tylko dla GBP. Wszystkie współczynniki korelacja są statystycznie istotne przy poziome ufności równym 95\%.

Źródło: opracowanie własne.

\section{Wykres 2}

Zakres poziomów wskaźników referencyjnych stóp procentowych
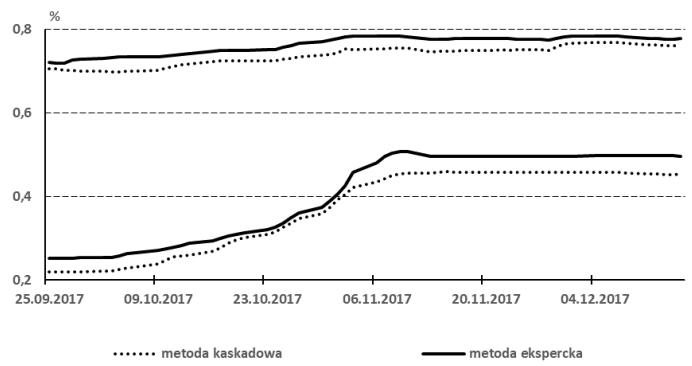

a) LIBOR

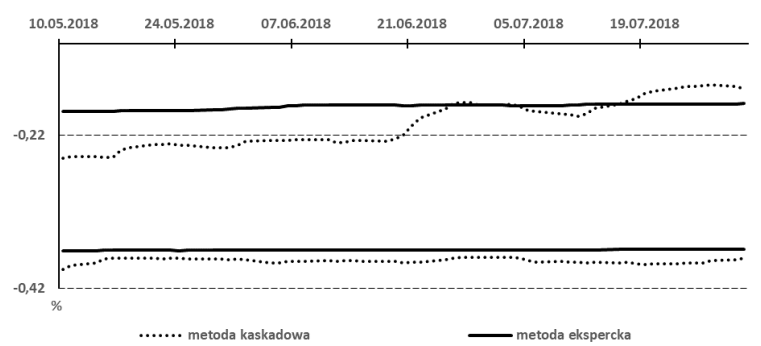

b) EURIBOR

Objaśnienia: uwzględniono terminy zapadalności od 1M do $12 \mathrm{M}$. Zastosowano średnią ruchomą z oknem 5 dni.

Źródło: opracowania własne.

${ }^{40}$ Miara tej zmienności jest odchylenie standardowe, w tym przypadku wyliczane dla dziennych zmian poziomu badanego wskaźnika referencyjnego stopy procentowej. 
Argumentacja prawna oraz ekonomiczna wskazują na brak podstaw do wątpienia w ciagłość prawną LIBOR bądź EURIBOR. W obu przypadkach administratorzy nadal odwołują się do realiów rynku niezabezpieczonych depozytów, początkowo międzybankowych, a obecnie nacisk przesunął się na rynek hurtowy, którego podzbiorem jest segment międzybankowy. Takie podejście odzwierciedla zmiany w strukturze rynku pieniężnego. Ponadto uczestnicy panelu zostali zobowiązani do tego, by przedstawiając (w ostateczności) kwotowania, konfrontowali je z realiami powiązanego rynku operacji zabezpieczonych (repo oraz instrumentów pochodnych). Zatem kwotowania stały się ekonomicznie weryfikowalne. Warto też pamiętać, że oprocentowanie nadal przekazują banki, których udział w panelu wynika z aktywności na badanym rynku. Dlatego autor uważa, że LIBOR oraz EURIBOR ustalane dzięki kaskadzie danych, pomimo modyfikacji charakteru danych wejściowych, nie zostały poddane istotnej zmianie, o której mowa w art. 13 ust. 1 BMR. Tym samym szersze niż do tej pory definiowanie podmiotów składających depozyty na rynku, na którym banki pozyskują kapitał pieniężny, oraz stosowanie „okna czasowego" powinno być traktowane jako ewolucja wymuszona zmianami realiów gospodarczych, która jest wręcz zalecana przez BMR. Dlatego nie powinny pojawiać się obawy o wywiązywanie się z umów odwołujacych się do wskaźników referencyjnych stopy procentowej, np. kredytu hipotecznego.

Z punktu widzenia stabilności rynku finansowego, a zwłaszcza interesów jego nieprofesjonalnego uczestnika, zamiast koncentrować się na reperkusjach ewentualnej istotnej zmiany metody ustalania wskaźnika referencyjnego stopy procentowej, warto podkreślić, że obecnie opracowywanie takich wskaźników jest działalnością nadzorowana. Tym samym kredytobiorcy detaliczni zyskują swoistą gwarancję prawna, iż wycenia płatności odsetkowych odpowiada wymogom regulacyjnym.

\section{PODSUMOWANIE}

Doświadczenia związane z kryzysem finansowym wykazały, że wyznaczanie wskaźników referencyjnych stopy procentowej na bazie eksperckich ocen jest ułomne. Stosowana metoda była podatna na manipulacje, gdyż kwotowania nie były powiązane $\mathrm{z}$ transakcjami. Z tego względu zrozumiałe jest poddanie procesu opracowywania poszczególnych IBOR reformie, której ramy wyznaczają zalecenia FSB-IOSCO, a także przepisy rozporządzenia 2016/1011.

W odniesieniu do LIBOR oraz EURIBOR zakończył się już jego bardzo ważny etap, gdyż administratorzy uzyskali zezwolenie na pełnienie tej funkcji. Równocześnie podkreślić należy, że zarówno w przypadku strefy euro, jak i Londynu dane o transakcjach niezabezpieczonych, które zawierane sa na rynku hurtowym, nadal muszą być uzupełniane ocenami eksperckimi. Z jednej strony wskazuje to na zmniejszoną płynność rynku międzybankowego, z drugiej - jest regulacyjnie dopuszczalne. W opinii autora zmienione zasady wyznaczania analizowanych wskaźników referencyjnych stopy procentowej 
należy uznać za udany kompromis równoważący dążenie do jak największej transkacyjności wskaźnika referencyjnego z dbałością o unikanie sytuacji zaprzestania jego opracowywania.

Ewolucja zasad wyznaczania LIBOR oraz EURIBOR musi rodzić pytania o zachowanie ciagłości wskaźników referencyjnych stopy procentowej wyznaczanych na podstawie wyłacznie kwotowania oraz obecnie stosowanej kaskady danych. W świetle przytoczonych w pracy argumentów, zarówno ekonomicznych, jak i prawnych, autor wskazuje na brak podstaw do twierdzenia, iż nastapiła istotna zmiana, o której mowa w art. 13 ust. 1 lit. c BMR.

\section{Michat Kruszka}

Akademia Finansów i Biznesu Vistla w Warszawie

m.kruszka@vistual.edu.pl

https://orcid.org/0000-0002-9138-7225

ARRC (2018). Second Report The Alternative Reference Rates Committee. <https://www.newyorkfed.org/medialibrary/Microsites/arrc/files/2018/ARRC-Second-report>.

Ashton, P., Chritophers, B. (2015). On arbitration, arbitrage and arbitrariness in financial markets and their governance: unpacking LIBOR and the LIBOR scandal. Economy and Society 44(2): 188-217.

Berman, B. (2015). How should structured product issuers and distributors respond to the IOSCO principles for financial benchmarks? The Journal of Investing 24(3): 107-115.

Bianchetti, M. (2013). Modern Pricing of Interest Rate Derivatives Including Funding and Collateral, [w:] M. Morinni, M. Bainchetti, Interest Rate Modelling after the Financial Crises, London: 113-152.

Chmielewski, T., Sławiński, A. (2010). Wykorzystanie instrumentów nadzorczych w polityce makrostabilnościowej. Zarządzanie Publiczne 3(13): 49-66.

Creel, J., Hubert, P., Viennot, M. (2016). The effect of ECB monetary policies on interest rates and volumes. Applied Economics 48: 4477-4501.

Duffie, D., Stein, J.C. (2015). Reforming LIBOR and other financial market benchmarks. Journal of Economic Perspectives 29(2): 191-212.

EBC (2018a). Update on quantitative mapping exercise. <https://www.ecb.europa.eu/paym/initiatives/interest_rate_benchmarks/WG_euro_risk-free_rates/shared/pdf/20180517/2018_05_17_ WG_on_euro_RFR_Item_3_1_Mapping_exercise_ECB.pd>.

Eisl, A., Jankowitsch, R., Subrahmanyam, M.G. (2017). The manipulation potential of Libor and Euribor. European Financial Management 23(4): 604-647.

EMMI (2017). Pre-Live Verification Program Outcome and Way Forward. <https://www.emmi-benchmarks.eu/assets/files/D0246B-2017_PLVP\%20public\%20report\%20and\%20way\%20 forward_FINAL.pdf>.

EMMI (2019a). EURIBOR Benchmark Statement. <https://www.emmi-benchmarks.eu/assets/files/D0246A-2019-EURIBOR\%20Benchmark\%20Statement_final\%20-\%20FINAL.pdf>.

EMMI (2019b). Benchmarks Changes and Cessation Policy. <https://www.emmi-benchmarks.eu/ assets/files/D0488D-2014-Benchmarks\%20Changes\%20and\%20Cessation\%20Policy.pdf>.

Ewerhart, C., Cassola, N., Ejerskov, S., Valla, N. (2007). Manipulation in money markets. International Journal of Central Banking 3(1): 113-148.

FSMA (2019). The FSMA Authorises EMMI as Administrator of the EURIBOR Benchmark. $<$ https://www.fsma.be/en/news/fsma-authorises-emmi-administrator-euribor-benchmark $>$.

Georg, C.-P. (2011). The Effect of the Interbank Network Structure on Contagion and Financial Stability. Bundesbank Research Centre Discussion Paper Banking and Financial Studies No. 12 . 
Gruszczyńska-Brożbar, E. (1999). Rynek długoterminowych kapitałów pieniężnych w strukturze rynku kapitałów pieniężnych. Ruch Prawniczy, Ekonomiczny i Socjologiczny 61(3/4): 137-149 .

Gyntelberg, J., Wooldridge, P. (2008). Interbank rate fixings during the recent turmoil. BIS Quarterly Review, March: 59-72.

HM Treasury (2012). The Wheatley Review of LIBOR: final report. <https://www.gov.uk/government/uploads/system/uploads/attachment_data/file/191762/wheatley_review_libor_finalreport_280912.pdf>.

Hörth, E. (1998). New reference rates in EMU. Deutsche Bank Research - EMU Watch No. 60.

IBA (2017). ICE LIBOR Output Statement. <https://www.theice.com/publicdocs/ICE_LIBOR_ Output_Statement.pdf>.

IBA (2018). ICE Benchmark Administration Becomes Authorised Benchmark Administrator Under EU Benchmark Regulation. <https://ir.theice.com/press/press-releases/all-categories/ 2018/04-30-2018-111621679>.

IBA (2019). ICE LIBOR - BMR Changes and Cessation Procedure. <https://www.theice.com/publicdocs/BMR_LIBOR_Change_Cessation_Procedure.pdf>.

Kapuściński, M., Kocięcki, A., Kowalczyk, H., Łyziak, T., Przystupa, J., Stanisławska, E., Sznajderska, A., Wróbel, E. (2016). Mechanizm transmisji polityki pieniężnej w Polsce. Co wiemy w 2015 roku? Materiały i Studia 323. Warszawa.

Klein, P. (2004). Interest rate swaps. Reconciliation of models. The Journal of Derivatives 12(1): $46-57$.

Lubiński, M. (2013). Międzybankowy rynek pieniężny i zarażenie. Gospodarka Narodowa 83/24(5/6): 19-41.

Martin, R. (2013). After economy? Social logics of the derivative. Social Text 31(1): 83-106.

McBride, J. (2016). Understanding the Libor Scandal. <https://www.cfr.org/backgrounder/understanding-libor-scandal>.

Mielus, P. (2016). Dylematy reformy indeksów rynku finansowego. Gospodarka Narodowa 86/27(4): 91-114.

Mishkin, F.S., Eakins, S.G. (2015). Financial Markets and Institutions. Harlow.

Mollenkamp, C., Whitehouse, M. (2008). Study casts doubt on key rate. Wall Street Journal, 28 May 2008. <https://www.wsj.com/articles/SB121200703762027135>.

MPG (2014). Market Participants Group on Reforming Interest Rate Benchmarks Final Report. $<$ https://www.fsb.org/wp-content/uploads/r_140722b.pdf $>$.

Nawrot, W. (2008). Rynek kapitałowy i jego rozwój. Warszawa.

Penczar, M. (2017). Consumer characteristics with regard to choosing between fixed and adjustable interest rates in mortgage contracts. Bezpieczny Bank 4(69): 131-146.

Tabb, R., Grundfest, J. (2013). Alternatives to LIBOR. Capital Markets Law Journal 8(3): $229-260$.

Vaughan, L., Finch, G. (2017). The Fix: How Bankers Lied, Cheated and Colluded to Rig the World's Most Important Number. Chichester.

\section{THE CONTINUED LEGAL VIABILITY OF INTEREST RATE BENCHMARKS}

$$
\text { Summary }
$$

The development of financial markets over the past few decades highlighted the very important role of financial benchmarks, which are used as a reference price for financial instruments or to determine interest payments. However, after the global financial crisis, allegations emerged that interbank interest rate benchmarks had been manipulated. A significant decrease in the size and importance of unsecured interbank transactions was observed as well. Both elements lower the credibility of the interest rate benchmarks used thus far. With the responsibility for financial stability in mind, the European Parliament and the Council of the European Union adopted a regulation on benchmarks (BMR) in 2016. The main purpose of this paper is to verify the hypothesis of the occurrence of material change, which could undermine continued legal viability of interest rate benchmarks. The main subject of the analysis was the development of the 
EURIBOR and LIBOR methodology. The results of the analysis showed that the new waterfall methodology, which utilizes eligible interbank transaction data, transaction-derived data, and data-based expert judgement, is a robust evolution of the quote-based methodology. This means that administrators did not change the benchmark's underlying interest, and no one should diagnose the risk to the continued legal viability of EURIBOR and LIBOR rates.

Keywords: interest rate benchmark; BMR; EURIBOR; LIBOR 
